\title{
American Consumer's Attitudes towards Different Airline Companies Channels: A Comparison of transaction Methods
}

\author{
Talha Harcar ${ }^{\mathrm{i}}$ \\ Ugur Yucelt ii
}

Penn State University (U.S.A.)

\begin{abstract}
Consumers are increasingly challenging better performance from companies, and these demands are being met through improvements in technology and flexibility of services. As a result of recent progresses and developments in electronic marketing, the physical locations of brick and mortar businesses have become less significant since transactions can now be accomplished in cyberspace. In this paper, consumer attitudes towards online transactions for the airline industry are examined. Despite the growing acceptance of alternative delivery channels, the travel agencies remain an essential part of the customer-airline company. It can be argued that the travel agencies not only represent an opportunity for implementing costumer relationship, but they also remain an important point of contact for sales, service, and consultative interactions. Data has been analyzed using factor analysis technique. The study presents a broad picture of the level of preference of airline customers among the available distribution channels and sheds light on how airline companies should allocate resources among the different channels. The empirical study findings indicate that online transactions for the airline industry will gain in importance and its use will accelerate at a faster rate in the coming years.
\end{abstract}

Keywords: Airline company; Online ticketing; Online shopping; Consumer behavior; Electronic commerce; Electronic marketing.

Título: Actitudes de los Consumidores Americanos hacia los Diferentes Canales de las Compañías Aéreas: Comparación de Métodos de Transacción

Resumen: Los consumidores cuestionan cada día más el rendimiento de las empresas, y estas intentan cumplir estas demandas con mejoras en la tecnología y la flexibilidad de los servicios. Debido al avance y desarrollo del marketing electrónico, la ubicación física de las empresas ha perdido importancia ya que las transacciones se pueden realizar en el ciberespacio. En este trabajo, se examinan las actitudes del consumidor hacia las transacciones online de la industria aérea. A pesar de la creciente aceptación de los canales alternativos de distribución, las agencias de viaje siguen siendo una parte esencial de la relación cliente-aerolínea. Se puede argumentar que las agencias de viaje no sólo representan una oportunidad para la relación con el cliente, sino que además siguen siendo esenciales como punto de contacto para ventas, servicio y consulta. Los datos han sido analizados mediante análisis factorial. El estudio presenta un panorama general sobre el nivel de preferencia de los clientes entre los diferentes canales de distribución de las aerolíneas y arroja luz sobre como las compañías aéreas deben asignar recursos entre los distintos canales. Los resultados del estudio empírico indican que las transacciones online para la industria aérea ganarán importancia y su uso se acelerará a un ritmo rápido en los próximos años.

Palabras clave: Compañía aérea; Venta de billetes online; Compras online; Comportamiento del consumidor; Comercio electrónico; Marketing electrónico.

i Business and Economics Division, Penn State-Beaver, tdh13@psu.edu.

ii School of Business Administration, Penn State-Harrisburg, uqy@psu.edu. 


\section{Introduction}

Since 1995, the Internet has become the way of life for millions of people worldwide. Accordingly, the number of regular internet users became 130.6 million at the end of 1999. The industry analysts have estimated that the number of Internet users will be increased one million every month. With this rate of increase, there are now almost 2 billion Internet users in 2010, and the Internet has provided consumers more control in accessing information on products and services (Law and Leung, 2000; and internetworldstats.com, 2010). The reasons of this worldwide acceptance of the Internet are its benefits to its users. It can be used 24/7/365 times within a year, it offers lower prices and a large variety of goods and services, it is an effective way of communication, it is used for online banking and college education, product searching and online training/ seminars, and researching and buying on line (Besette, 2010). In addition, another study using multiple regression analysis showed evidence that security/privacy, word of mouth, good online experience, quality of information, and brand reputation are significant elements affecting online brand trust in the airline industry in Malaysia (Alam and Yasin, 2010).

However, the use of the Internet as an airline ticket purchase channel is not fully developed, because consumers use the Internet for research of airlines and airfare not for purchase of tickets as like many other product and service categories. Consumers pull for online content - they decide when, where, what, and how much commercial content they wish to view. Accordingly, the Internet allows consumers to reach a large variety of products and services from companies around the world. (Ko et al 2004 and Lim et al, 2010). A study (Manzona and Valpuesta, 2009) demonstrated that the profile of passengers who are more likely to make their bookings online is that of a young person between 15-30 years of age, more likely to be female, a students with high academic level, an habitual traveler, who is booking a trip that is not very complex or is to a destination that is already known. On the other hand, male internet users are 50-65 years old, on a business or short trip and requiring the services of a travel agency. In addition, Lee and Cheng (2010) discover that there is no significant difference between online and offline agencies in terms of total customer satisfaction; however, online agencies offer lower prices and faster service leading to switching from offline to onli- ne travel agencies.

Similar to all online purchases, airline ticket purchase is not immune to taking risk. Therefore, studies suggest that the most appropriate and effective way of minimizing online risk is through establishing trust (Kolsaker, Lee-Kelly and Choy, 2004). Accordingly, Ruiz-Mafe et al. (2009) identified risk dimensions as performance risk that includes the consumers' fear that products and services acquired may not meet their expectations. Psychological risk means fear of loss of self esteem due to wrong choice of product/service. Time risk is wasting time associated with online ticket purchase. Social risk relates to an unacceptable choice that it is considered embarrassing. Privacy risk is personal information that may be shared with others without the person's knowledge. Another study (Kim, Qu and Kim, 2009) stated that security risk is the most important predictor of the overall risk regarding the online purchase of air tickets. On the other hand, non-purchasers perceived a higher risk than online purchasers in terms of performance, security, financial, psychological, and time risks.

The travel industry was stricken during the recession as consumers and business travelers scaled back spending. Because of the diminishing waning revenue, airlines started to cut capacity and costs and charged customers for everything from beverages to checked luggage. With little left to slash, the airlines have been looking at their distribution-system costs as the next big frontier in terms of cutting expenses (Tibken, 2010). In recent years, airline companies have increasingly adopted internet-based systems to conduct traveling operations with other businesses, private consumers, and government departments/agencies. The airline industry is continuously enhancing and expanding services on the internet, including flight booking, payment options, electronic check-in, tracking of ticket prices and lost items, flight schedules, monitoring transaction history, customers' loyalty programs etc. One study in the Spanish Airline market showed that those more likely of making purchases by phone were male, middle-aged, on a business or short trip, and usually using a travel agency. Finally, passengers who are over 65 years of age, with a lower academic level, who use a travel agency and are going to make a more complicated journey, are more likely to purchase their tickets through traditional channels (Manzano and Valpuesta, 2009). Additionally, more hybrid travel arrangements will increase the attractiveness of the Internet across more diverse 
population strata. The results also show significant differences in the selection criteria of airline companies' online customers and traditional customers. This empirical study also offers important policy suggestions to current airline company managers in the study area. The customer survey also showed that customer channel preferences are different from actual usage rates.

\section{Research questions and purpose of the study}

A growing number of consumers recognize that online functions save time, and on the other hand airline industry believes that the Internet ties their best customers more closely to their organization. On the other hand despite the efforts of airline companies towards getting consumers to take advantage of Internet purchases, the travel agencies remain an essential part of the customer-airline interaction. It can be argued that the travel agencies not only represent an opportunity for implementing customer relationship, but it also remains an important point of contact for sales, service, and consultative interactions. Consumers are increasingly challenging better performance from companies, and these demands are being met through improvements in technology and flexibility of services. Since the Internet usage has been growing in recent years, research opportunities on online and offline purchasing behaviors have become more important. Therefore, offline and online purchasing experiences have been studied and researchers have tried to identify differences regarding those two groups of consumers (Hamilton and Thompson, 2007; Ko, et al., 2004; Zhang, 2006; Wang, 2009). As a result of recent progresses and developments in electronic marketing, the physical location of several companies has become less significant since transactions can now be accomplished in cyberspace. Internet has provided consumers more control in accessing information on products and services. Consumers pull for online content - they decide when, where, what, and how much commercial content they wish to view.

The Internet allows consumers to reach a large variety of products and services from companies around the world (Ko et al., 2004; Lim et al., 2010). The travel industry was stricken during the recession as consumers and business travelers scaled back spending. Because of the diminishing waning revenue, airlines started to cut capacity and costs and charged customers for everything from beve- rages to checked luggage. With little left to slash, the airlines have been looking at their distributionsystems in order to cut expenses (Tibken, 2010). In recent years, airline companies have increasingly adopted internet-based systems to conduct traveling operations with other businesses, private consumers, and government departments/agencies. The airline industry is continuously enhancing and expanding services on the internet, including flight booking, payment options, electronic check-in, tracking of ticket prices and lost items, flight schedules, monitoring transaction history, costumers' loyalty programs etc.

\section{Methodology}

\section{Data Collection}

The data for this study was collected through self-administered questionnaires that were administrated in rural parts of Western Pennsylvania (Beaver, Allegheny, and Butler counties). Stratified sampling with proportional allocation was used for sampling. The data was collected through a drop-off and pick-up method among a sample of 300 Beaver, Allegheny and Butler county residents. The dropoff/pick-up is a data-gathering technique that includes the advantages of both personal interviews and self-administered questionnaires Imperia et al 1985). Interviews were conducted by marketing research students under the supervision of one of the researchers in each locality. Respondents were randomly contacted by telephone at their workplace or their home and asked if they wanted to participate to this study. For those who agreed to participate, a questionnaire was delivered to their given address, and they were asked to complete the questionnaire at their most convenient time. Arrangements were then made to pick up the completed questionnaires at a specified time, generally ten days later. The survey instrument was left at each pre-selected household, and approximately 10 days later the surveys were personally retrieved by the selected students of Beaver campus of Pennsylvania State University. A total of 325 questionnaires were retrieved, but, only 319 usable questionnaires were attained due to incompleteness and other survey operations problems.

Measurement Development and Questionnaire Design

A variety of dependent and independent constructs and measures have been employed to iden- 


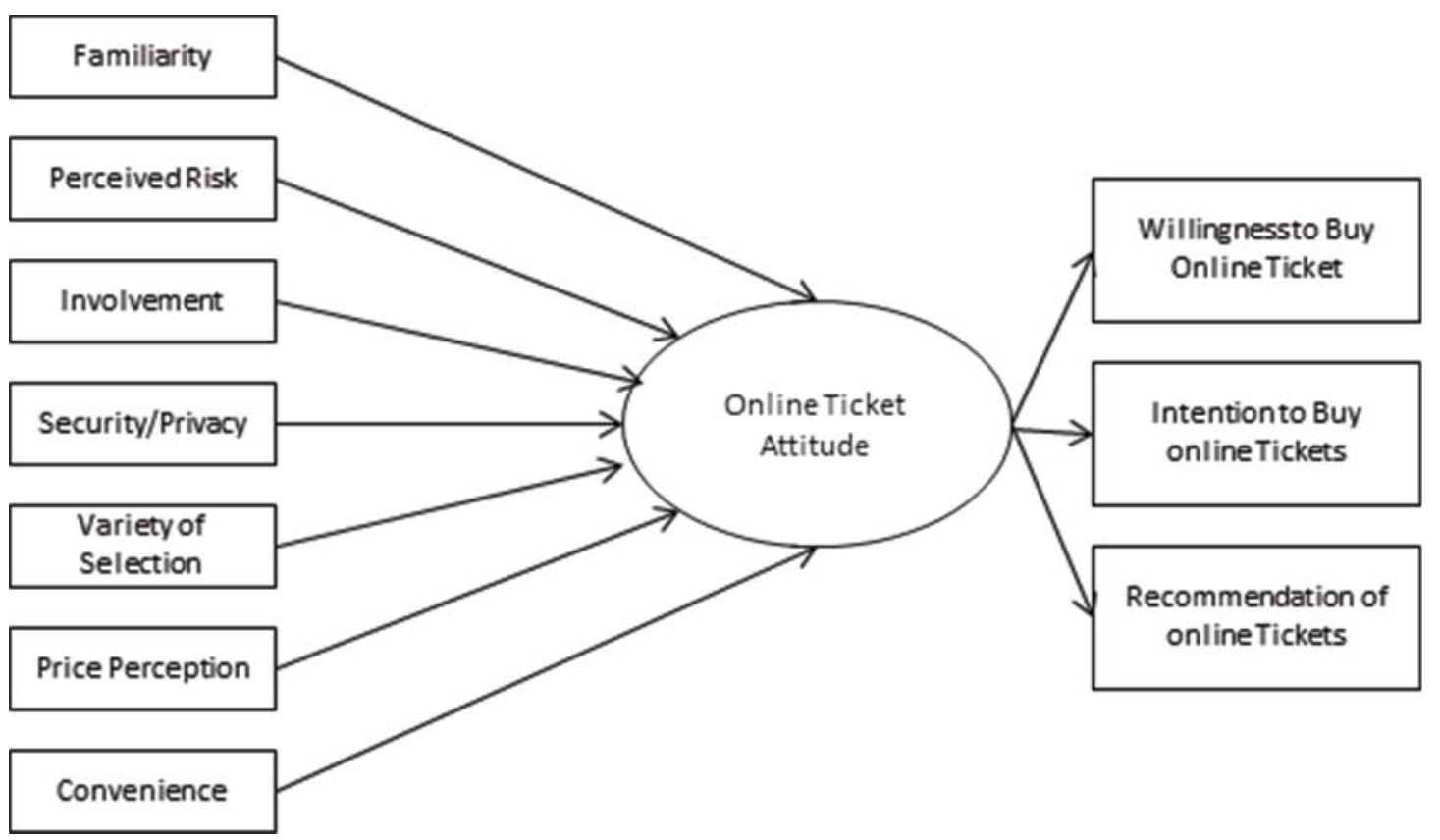

Figure 1. Online Airline Tickets Attitude Model

tify the drivers of online ticket attitudes. There is no recognized design that can be directly applied to operationalize the constructs of consumer attitudes towards online tickets proposed in this study. The measures used in this study came from a number of different sources. Some items of the constructs were developed by the researchers, while some were adopted or modified from previous researches. (Table 1).

The questionnaires were divided into four parts. The first part deals with general usage patterns of the Internet and examines how frequent respondents use the Internet in a week and the amount of online tickets they buy on the Internet. The independent variables were online ticket perceptions. Each item was formulated as a statement for which the subjects had to indicate the extent of agreement on a 7-point scale going from (1) strongly disagree to (7) strongly agree. The 22 items are listed in Table 1. In the questionnaire the items were actually randomly ordered. The third part in order to measure online ticket attitude included three questions a) willingness to buy, b) recommendation and c) probability to consider buying online in the future were used with a Likert scale from (5) definitely willing to buy, recommend, will buy in the future to (1) definitely not willing to buy, not recommend and not buy in the future. Final part includes a number of demographic information of the respondents.

\section{Findings}

Demographic Characteristics of Respondents and Online Ticket Purchase

The data set consists of 136 online tickets purchasers (47.4\%) and 151 traditional travel agency purchasers $(52.6 \%)$. The demographic and socioeconomic profile of the respondents is presented in Table 2.

To assess the statistical significance of differences in demographics and online ticket usage cross tabulation and a Chi-square test of association were performed. A close examination of the profile depicts that while online ticket customer and travel agency customers showed statistically significant differences in demographic characteristics. Online ticket users were mostly male, high income earners consisted of younger age groups, held more professional, and trade related types of jobs, craftsman, students and unemployed.

The sample consisted of about 49.5 male and 50.5 female bank customers. Online ticket web service female users are $38.6 \%$ of the total female sample while $56.3 \%$ of male respondents are online ticket users. The ratios for nonusers related to gender are $61.4 \%$ female versus $43.7 \%$ of males. About $51.7 \%$ of 25 years and younger group were online ticket users, online ticket users have the highest ratio 57.3 $\%$ of the 26-45 year group, between $45-65$ years old group account (47.7\%) for online ticket practices 


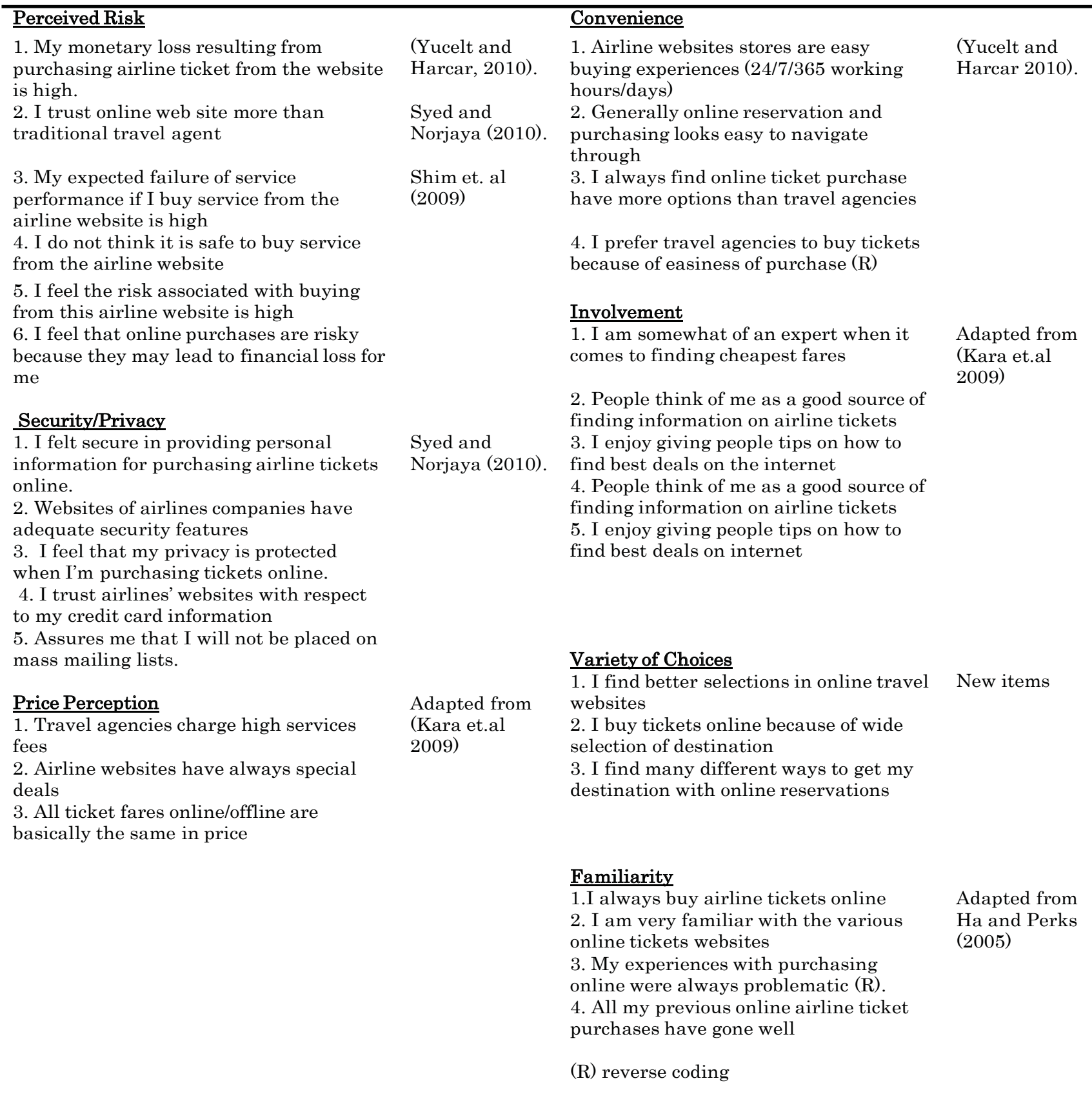

Table 1: Measure Used for Online Ticket Purchase Attitudes

while over 65 years old group have the lowest usage rate $(12.5 \%)$. Online ticket users comprised $53.6 \%$ of university graduates, while the ratios are $60.9 \%$ for vocational schools, $44.6 \%$ for high schools, 55.6 for secondary school and \%16 for primary schools. With regard to occupation, $55.4 \%$ of professionals were using online banking. All other occupation distributed between online banking users and nonusers can be found on Table 2 .
Additionally, the time spent on the internet was also investigated. There were statistically significant differences between online ticket users and non-users on internet usage.

\section{Factors Affecting Online Ticket Purchase}

Using the 'factor analysis' module in SPSS, the "factors affecting online ticketing/travel agency 


\begin{tabular}{|c|c|c|c|c|}
\hline & $\begin{array}{c}\text { Online Ticket } \\
(n=136)\end{array}$ & $\begin{array}{c}\text { Travel Agency } \\
(n=151)\end{array}$ & Total & Chi Square \\
\hline Gender & & & & $9.03(*)$ \\
\hline Male & $56.3 \%$ & $43.7 \%$ & $49.5 \%$ & \\
\hline Female & $38.6 \%$ & $61.4 \%$ & $50.5 \%$ & \\
\hline Age & & & & $14.71\left(^{*}\right)$ \\
\hline Under 25 & $51.7 \%$ & $48.3 \%$ & $20.9 \%$ & \\
\hline $26-45$ & $57.3 \%$ & $42.7 \%$ & $44.6 \%$ & \\
\hline $46-65$ & $47.7 \%$ & $52.3 \%$ & $26.1 \%$ & \\
\hline Over 65 & $12.5 \%$ & $87.5 \%$ & $8.4 \%$ & \\
\hline Education & & & & $16.04(*)$ \\
\hline Primary School & $16.0 \%$ & $84.0 \%$ & $8.7 \%$ & \\
\hline Secondary School & $55.6 \%$ & $44.4 \%$ & $9.4 \%$ & \\
\hline High School & $44.6 \%$ & $56.4 \%$ & $40.8 \%$ & \\
\hline Vocational School & $60.9 \%$ & $39.1 \%$ & $24.0 \%$ & \\
\hline University & $53.6 \%$ & $46.4 \%$ & $17.1 \%$ & \\
\hline Occupation & & & & $16.01\left(^{*}\right)$ \\
\hline Professional & $54.5 \%$ & $45.5 \%$ & $16.8 \%$ & \\
\hline Administrative & $46.9 \%$ & $53.1 \%$ & $15.0 \%$ & \\
\hline Trade Man - Sales Man & $55.6 \%$ & $44.4 \%$ & $16.5 \%$ & \\
\hline Housewife & $32.4 \%$ & $67.6 \%$ & $11.3 \%$ & \\
\hline Technical & $48.5 \%$ & $51.5 \%$ & $10.1 \%$ & \\
\hline Craftsman & $56.0 \%$ & $44.0 \%$ & $7.6 \%$ & \\
\hline Student & $62.9 \%$ & $37.1 \%$ & $10.7 \%$ & \\
\hline Unemployed & $74.4 \%$ & $25.6 \%$ & $11.9 \%$ & \\
\hline Income & & & & $17.59\left({ }^{*}\right)$ \\
\hline Low & $39.7 \%$ & $60.3 \%$ & $20.8 \%$ & \\
\hline Medium & $50.6 \%$ & $49.4 \%$ & $53.8 \%$ & \\
\hline High & $72.3 \%$ & $27.7 \%$ & $25.4 \%$ & \\
\hline Internet Usage & & & & $22.08\left(^{*}\right)$ \\
\hline $\begin{array}{l}\text { Light Users less than } 5 \text { hours } \\
\text { a week }\end{array}$ & $33.0 \%$ & $67.0 \%$ & $27.8 \%$ & \\
\hline $\begin{array}{l}\text { Medium Users 6-15 hours a } \\
\text { week }\end{array}$ & $62.3 \%$ & $37.7 \%$ & $39.8 \%$ & \\
\hline $\begin{array}{l}\text { Heavy Users more than } 15 \\
\text { hours a week }\end{array}$ & $61.3 \%$ & $38.7 \%$ & $32.4 \%$ & \\
\hline
\end{tabular}

(*) significant relationship for 0.01 significance level

Table: 2 Demographic and Socio-Economic Characteristics of the Sample

purchasing behaviors" were analyzed. The principal components' method for initial factor extraction with the criterion Eigenvalue greater than 1 and Varimax method of rotation was applied. Sample size is an element that can affect the adequacy of the factor models. It has been suggested (Hayes, 1992) that the sample size should equal at least 10 times the number of variables; for large numbers of variables the proportion is decreased to five. In similar studies samples of size approximately 200 were chosen (Parasuraman et al., 1988). Sample size for this survey was 287 as it is mentioned above. All the items were first factor analyzed. Rotated factor loadings were examined assuming different numbers of factors for extraction. As this was based on student data only, the adequacy of the sample size was questionable; the results showed no interpretable grouping of items. Deleting 4 different statements; convenience2, familiarity3, 4 and in- volvement4 all the online ticketing/travel agency purchasing responses could be incorporated into the analysis. This was carried out. The results showed considerable improvement over the previous attempt as some meaningful patterns emerged and it has been found that there are seven different factors related to the online ticketing/travel agency purchasing behavior; perceived risk, security/privacy, price perception, variety of selection, involvement, familiarity and convenience. Table 3 depicts the sorted rotated factor loadings for the items based on seven-factor extraction. The total figure of $73.93 \%$ represents the percentage of variance of all 27 items explained by the seven factors. In this study, the internal consistency (Cronbach's a) for the 27-itemscale was .91. The Cronbach's a coefficients for the positive and negative items of the indecisiveness scale were .83 and .86 respectively. To test the appropriateness of factor analysis, the Kaiser- 


\begin{tabular}{|c|c|c|}
\hline & Factor Load & $\%$ of Variances \\
\hline FACTOR 1: Perceived Risk & & 20.339 \\
\hline $\begin{array}{l}\text { My monetary loss resulting from purchasing airline ticket } \\
\text { from the website is high. }\end{array}$ & .806 & \\
\hline I trust online web site more than traditional travel agent & .818 & \\
\hline $\begin{array}{l}\text { My expected failure of service performance if I buy service } \\
\text { from the airline websites high }\end{array}$ & .771 & \\
\hline $\begin{array}{l}\text { I do not think it is safe to buy service from the airline } \\
\text { website }\end{array}$ & .728 & \\
\hline $\begin{array}{l}\text { I feel the risk associated with buying from this airline } \\
\text { website is high }\end{array}$ & .779 & \\
\hline $\begin{array}{l}\text { I feel that online purchases are risky because they may lead } \\
\text { to financial loss for me }\end{array}$ & .768 & \\
\hline FACTOR $2:$ Security/Privacy & & 15.967 \\
\hline $\begin{array}{l}\text { I felt secure in providing personal information for } \\
\text { purchasing airline tickets online. }\end{array}$ & .914 & \\
\hline Websites of airlines company has adequate security features. & .901 & \\
\hline $\begin{array}{l}\text { I feel that my privacy is protected when I'm purchasing } \\
\text { ticket online. }\end{array}$ & .857 & \\
\hline $\begin{array}{l}\text { I trust airlines websites with respect to my credit card } \\
\text { information }\end{array}$ & .785 & \\
\hline Assures me that I will not be placed on mass mailing lists. & .775 & \\
\hline $\begin{array}{l}\text { Assures me that my personal information will not be shared } \\
\text { with marketing organizations. }\end{array}$ & .690 & \\
\hline FACTOR 3 : Price Perception & & 13.71 \\
\hline Airline website offer lower fares & .921 & \\
\hline Travel agencies charges high services fees & .943 & \\
\hline Airline websites have always special deals & .825 & \\
\hline All ticket fares online/offline are basically the same in price & .623 & \\
\hline FACTOR 4 : Convenience & & 8.54 \\
\hline $\begin{array}{l}\text { Airline websites stores are easy buying experiences (24/7/365 } \\
\text { working hours/days) }\end{array}$ & .959 & \\
\hline $\begin{array}{l}\text { I always find online ticket purchase have more options than } \\
\text { travel agencies }\end{array}$ & .954 & \\
\hline $\begin{array}{l}\text { I prefer travel agencies to buy tickets because of easiness to } \\
\text { purchase }(R)\end{array}$ & .932 & \\
\hline FACTOR $5:$ Involvement & & 6.96 \\
\hline $\begin{array}{l}\text { I am somewhat of an expert when it comes to finding } \\
\text { cheapest fares }\end{array}$ & .911 & \\
\hline $\begin{array}{l}\text { People think of me as a good source of finding information on } \\
\text { airline tickets }\end{array}$ & .899 & \\
\hline $\begin{array}{l}\text { I enjoy giving people tips on how to find best deals on } \\
\text { internet }\end{array}$ & .883 & \\
\hline FACTOR $6:$ Variety of Choices & & 3.95 \\
\hline I find better selections in online travel websites & .648 & \\
\hline I buy tickets online because of wide selection of destination & .632 & \\
\hline $\begin{array}{l}\text { I find many different ways to get my destination with online } \\
\text { reservations }\end{array}$ & .631 & \\
\hline FACTOR $7:$ Familiarity & & 4.42 \\
\hline I buy airline ticket always online & .761 & \\
\hline I am very familiar with the various online tickets websites & .722 & \\
\hline
\end{tabular}

Table 3. Factors Affecting Online/Traditional Ticket Purchasing Behaviors 
Meyer-Olkin (KMO) measure of sampling adequacy was conducted. The KMO was 0.876 , which is very close to the excellent level, 0.92. Bartlett's test of sphericity reveals significance at a level of 0.000 (Chi-square $=7624.342)$. The result supports the reliability and validity of the constructs.

The associations between willingness to buy online tickets, recommending buying tickets online, intention to buy in the future and factor effecting consumer behavior were tested by regression analysis. The results are analyzed to show that factors affecting buying behavior online contribute significantly and predict $0.849,0.816$ and 0.907 of the variation in willingness to buy online tickets, recommending buying tickets online, and intention to buy in the future respectively. We also examined the ANOVA values for the regression model in Table 2. All predictors except perceived risk and familiarity for willingness to buy, convenience, involvement and variety of selection for recommendation and perceived risk for intention to buy in the future have significant impact on online shopping. another, to examine the attitudes and characteristics of customers of this new market segment. Online ticketing is offered by all airline companies. In this paper, consumer attitudes towards online purchasing for the airline industry are examined. Furthermore the purpose of this study is to examine the online ticket purchase behavior by using a conceptual model, which incorporates various factors (such as price perception, convenience, security/brand, perceived risk, involvement, familiarity, variety of selection) that assumed to influence the online ticket purchase behavior. A research model based on the above literature review of different factors related with the online purchase attitude is presented in Figure 1. As you can follow in Figure 1 the consequences of consumer attitude to an online tickets site is illustrated in this model. A variety of factors that might affect a consumer's overall trust are listed under five major sources of trust. Additionally, the mentioned factors affect the intention, willingness and recommendation of online ticket $\mathrm{pa}^{-}$ tronage.

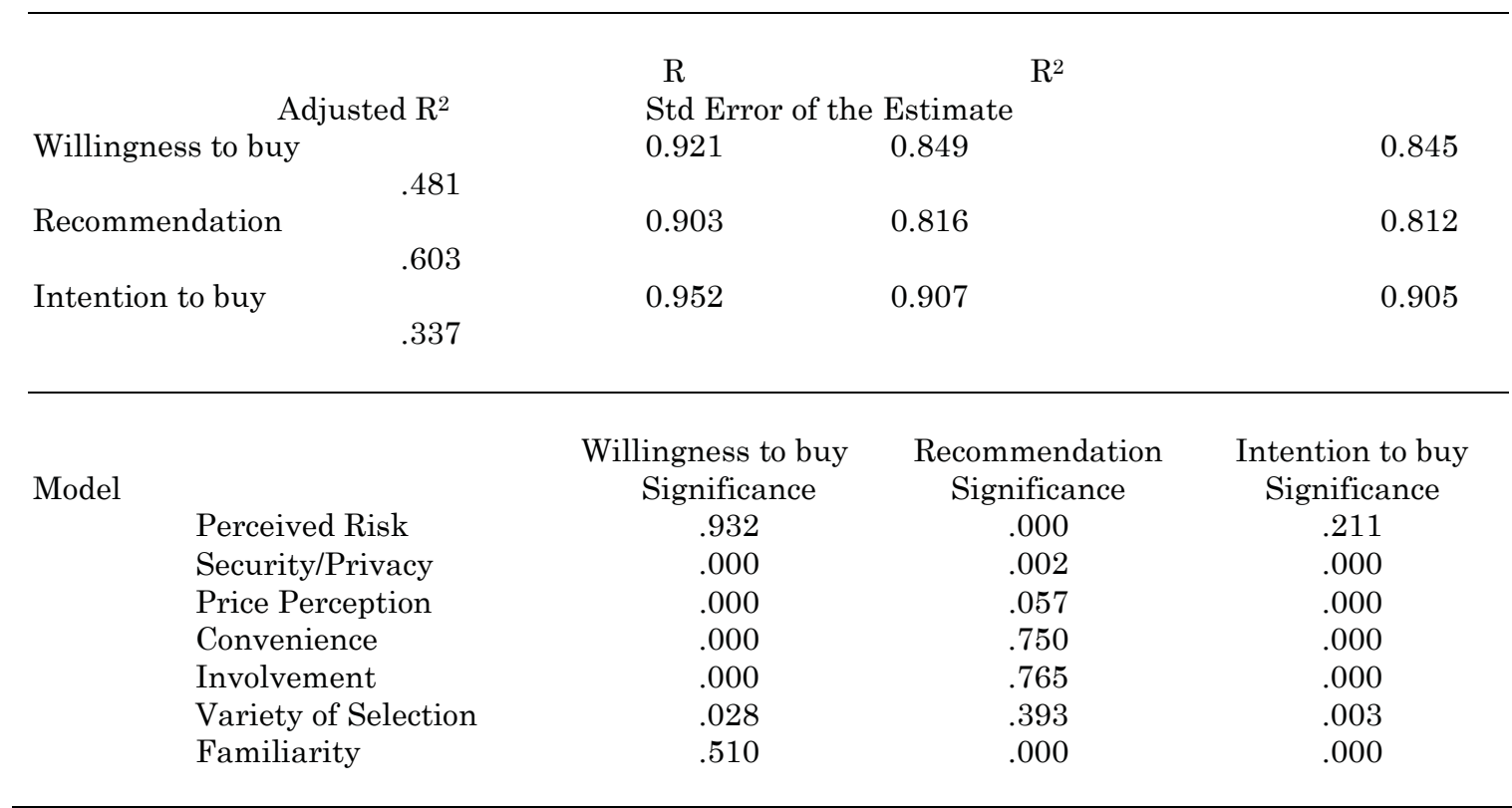

Table 4. Regression Model and ANOVA Summary for Willingness to Buy, Recommendation and Intention to Buy

\section{Conclusions and discussions}

Recognizing the enormous rise in the number of customers, who are buying airline tickets online during recent years, a number of airline companies are seeking to shift even more people to online ticketing. Airline companies are forced, in one way or
Regarding demographic differences in online/offline shopping preferences, our study results show consistency with those reported by Swinyard and Smith (2003). This research confirmed no relationship between willingness to buy airline tickets online and familiarity and perceived risk. It should be also noted that there was no evidence of relationship 
between recommendation of buying airline tickets online and convenience, involvement and variety of selection.

This study presents us with a broad picture of level of preference of airline customers among the available distribution channels and sheds light on how airline companies should allocate resources among the different channels. The empirical study findings indicate that online transactions for airline industry will gain in importance and its use will accelerate at a faster rate in the coming years. As well, more hybrid travel arrangements will grow attractiveness across diverse population strata. The results also show significant differences in the selection criteria of airline companies' online customer and traditional customers. This empirical study also offers important policy suggestions to current airline company managers in the study area. The customer survey also showed that customer channel preferences are different from actual usage rates. An outline of online airline ticketing identified seven factors; perceived risk, security/privacy, price perception, variety of selection, involvement, familiarity and convenience.

The limitation in terms of location (Western Pennsylvania) and respondent profile may have affected the outcomes. Upcoming research might also look at conducting studies simultaneously in different countries, with more attention given to cultural differences and environmental factors.

\section{References}

Alam, Syed Shah and Norjoya Mohd Yasin

2010. "What factors influence online brand trust: Evidence from online tickets buyers in Malaysia". Journal of Theoretical and Applied Electronic Commerce Research, 5(3): 78-89.

Besette, Bob

2010. "10 Life changing benefits of the Internet age" Communication, $21^{\text {st }}$ July. In http://workawesome.com/communication, pp 1-3.

Ha Hong-Youl and Helen Perks

2005. "Effects of consumer perceptions of brand experience on the Web: Brand familiarity, satisfaction and brand trust". Journal of Consumer Behavior, 4(6): 438-52, 2005.

Hamilton, Rebecca W. and D. V. Thompson

2007. "Is there a substitute for direct experience? Comparing consumer' preferences after direct and indirect product experiences". Journal of Consumer Research, 34: 546-555.
Hayes, Bob E. 1992. Measuring Customer Satisfaction Milwaukee. ASQC.

Imperia, Giovanna, Thomas C. O'Guinn and Elizabeth A. MacAdams

1985. "Family decision making role perceptions among Mexican-American and Anglo wives: a cross-cultural comparison". Advances in Consumer Research, 12: 71-74.

Kara, Ali, José I. Rojas-Mendez, Orsay Kucukemiroglu and Talha Harcar

2009. "Consumer preferences of store brands: Role of prior experiences and value consciousness". Journal of Targeting, Measurement and Analysis of Marketing, 17(2): 127-137.

Kim, Lisa Hyunjung, Haikin Qu and Dong Jim Kim 2009. "A study of perceived risk and risk prediction of purchasing air tickets online". Journal of Travel and Tourism Marketing, 26: 203-224.

Ko, Hanjun, Jaemin Jung, Joo Young Kim and Sung Wook Shim

2004. Cross-cultural differences in perceived risk of online shopping. Journal of Interactive Advertising, 4(2). Retrieved December 16, 2007, from http ://www.j iad.org/vol4/no2/ko .

Kolsaker, Ailsa, Liz Lee-Keiley and Pul Ching Choy 2004. "The reluctant Hong Kong consumer: Purchasing travel online”. Journal of Consumer Studies, 28: 295-304.

Law, Rob and Rita Leung

2000. "A Study of airlines online reservation services on the internet". Journal of Travel Research, 39(2): 202-211.

Lee, $\mathrm{Zu}-\mathrm{Hsu}$ and Kuangnen Cheng

2010. "Predictors of customer preference for online versus offline air travel booking". Tourism Review International, 13: 183-200.

Lim Yet Mee, Yap Ching Seng, Lau Teck Chai.

2010. "Online search and buying behaviour: Malaysian experience". Canadian Social Science, 6(4); pp. 154-167.

Manzano, José I Castillo and Valpuesta Lourdes López

2009. "The decline of the traditional travel agent model". Transportation Research. Part E, Logistics \& Transportation Review, 46(5): 639.

Parasuraman, A., Valarie A. Zeithaml, and Leonard L. Berry.

1985. "Conceptual model of service quality and its implications for further research". Journal of Marketing, 49(Fall): 41-50.

Ruiz-Mafe, Carla, Silvia Sanz-Bias and Joaquin Aldas-Manzonma

2009. "Drivers and barriers to online airline ticket 
purchasing". Journal of Air Transportation Management, 34: 294-298.

Shim, Soyeon, Mary Ann Eastlick, Sherry Lotz, and Patricia Warrington

2001. "An online prepurchase intentions model". Journal of Retailing, 77: 397-416.

Swinyard, Willima R. and Scott M. Smith

2003. "Why people (don't) shop online: a lifestyle study of the internet consumer". Psychology and Marketing, 20: 567-597.

Syed Shah Alam and Norjaya Mohd Yasin

2010. "What factors influence online brand trust: evidence from online tickets buyers in Malaysia". Journal of Theoretical and Applied Electronic Commerce Research, 5(3): 78-89

Tibken Shara

2010. "American Airlines to pull flights from Orbitz web site; airline's action would take effect Dec. 1 unless the two can agree on how the online travel agent gets the listings". Wall Street Journal, Nov 5, 2010.

Vida, Ivea and James Reardon

2008. "Domestic Consumption: Rational Affective or Normative Choice". Journal of Consumer Marketing. 25: 34-44.

Wang, Chung-Yu 2009. Investigating antecedents of consumers' recommend intentions and the $\mathrm{mo}^{-}$ delling effect of switching barriers". The Service Industries Journal, 29(9): 1-11.

World Internet Usage Statistics

2010. Available in www.internetwoldstats.com/ stats.htm

Yucelt, Ugur, Harcar, Talha. 2010

"An Empirical Investigation of Factors Effecting Purchasing Behaviors: Intentions, Experiences and Choices". Proceedings of 17th International Conference of the European Institute of Retailing and Services Studies (EIRASS), Istanbul, Turkey, July-2-5.

Zhang, Jie (2006). "An integrated choice model incorporating alternative mechanism for consumers' reaction to in-store display and feature advertising". Marketing Science, 25(May-June): 278-290.
Recibido:

$15 / 02 / 2011$

Reenviado:

Aceptado:

$30 / 09 / 2011$

$31 / 10 / 2011$ 